\title{
ENERGY MANAGEMENT MODEL FOR ENVIRONMENTAL PROTECTION IN INDUSTRY
}

\author{
UDC 620.9:502.171
}

\section{Milena Rajić1, Rado Maksimović , Pedja Milosavljević ${ }^{1}$, Marko Mančić1, Milena Mančićć, Dragan Pavlović}

${ }^{1}$ Department of Management in Mechanical Engineering, University of Niš, Faculty of Mechanical Engineering, Nišs, Serbia

${ }^{2}$ Department of Industrial Engineering and Management, University of Novi Sad, Faculty of Technical Sciences, Novi Sad, Serbia

${ }^{3}$ University of Niš, Faculty of Occupational Safety, Niš

\begin{abstract}
Sustainable business development and companies' market positioning require companies to maximize added value with minimal resource utilization. The rational use of energy and energy sources is also a growing challenge, which aims to preserve the environment. Industrial systems, primarily production systems, are the largest energy consumers. The need for this theme is the pressure of European regulation on the implementation of energy-saving measures as well as to have a positive impact on the environment. The standard for the energy management system, which is used in this research, consider the energy performance and energy performance indicators. One of the well-known representatives of this type of standard is ISO 50001. The aim of the paper is to analyze the energy demand in a production organization, to have insight into material and energy flows in the process, in order to form an energy management model. The model was developed with process parameters that are changed on daily basis.
\end{abstract}

Key words: energy management, energy flow, environmental protection, industrial system, MFEA

\section{INTRODUCTION}

The constant need for sustainable business and maintaining the market position requires industrial systems to maximize added value with minimal resource utilization. An increasing number of researchers emphasize the importance of developed models for managing material and energy flows in production organizations [1-7]. Rational use of energy and energy resources represents an increasing challenge for companies in Serbia and the world, all to preserve the environment. Research on material and energy flows,

Received June 17, 2020 / Accepted October 5, 2020

Corresponding author: Milena Rajić

Department of Management in Mechanical Engineering, University of Niš, Faculty of Mechanical Engineering, Aleksandra Medvedeva 14, 18000 Niš, Serbia

E-mail: milena.rajic@masfak.ni.ac.rs 
their correlations and the formation of models that are flexible and applicable to different production and service activities, will provide enough information to design processes with resource savings and a negative impact on the environment.

Industrial systems, primarily production systems, represent one of the major energy consumers. The production industry represents the most analyzed systems [8-13]. Using the standard procedures for monitoring consumption, the impact of material flow on energy consumption is presented in [14] and correlations of these flows are analyzed in $[15,16]$. Industrial systems, driven by high production costs and limited material resources, have made significant progress in achieving high system performance through innovative energy savings solutions and redesigning production processes [17-19].

Energy prices and costs of energy flows are some of the basic factors that determine production processes. Over $80 \%$ of the energy need in the industry is covered by the use of fossil fuels [20]. It is important to emphasize that the cost reduction is one of the critical elements in proper energy management, as energy savings reduce production costs, increase profits and reduce product prices [21].

In 2000 , the industry sector used $32 \%$ of the total final energy in the world, as it was indicated in a study on energy saving potentials in the industry [22]. Energy use in the industrial sector varies from 30 to $70 \%$ of the total energy in different countries [23]. The presented data indicate the importance of energy management in the industrial sector, which is one of the most important priorities for monitoring and analysis [24-26].

According to the data [27], energy consumption in Serbia is 2-3 times higher than in the countries of the European Union. According to the data of the Republic Statistical Office in Serbia for 2014 [28], energy consumption in the industrial sector was $31.17 \%$ share of the total final energy consumption in Serbia, while electricity consumption was $26.19 \%$. It can be noticed that energy consumption in the industrial sector has a significant share. Therefore, all resources for possible energy savings and proper energy management should be focused on this sector. The aim of this paper is to present the developed energy management model in the production organization, in order to identify, analyze and optimize energy flows in production processes. The analysis of energy performance within the organization is given, including energy consumption data and production data for 2018. Based on available data and obtained results, an energy performance indicator overview for 2018 has been given, as well as the estimated energy consumption for the future production period.

\section{MATERIAL Flow AND ENERGy PROFILE OF THE INDUSTRIAL PROCESS}

\subsection{Material flow in the production process}

The need to monitor and optimize energy flow is especially important for production organizations. To have a complete insight into energy consumption (electricity, heat, water, etc.) represents a priority in production planning especially nowadays. The production process optimization is discussed in particular in the automotive sector, where competitive conditions do not allow losses - material waste and other resources, as well as unforeseen energy costs. The production process in the automotive industry also characterizes the Justin-time (JIT) production, with a completely closed production cycle, without unnecessary movements, material accumulation and waste of resources. Authors have emphasized that the automotive sector represents a model of effective energy management [29-37]. 
The material flow of the analyzed production organization is presented in Fig 1, which is in the automotive sector in south-eastern Serbia selected for a case study related to energy management.

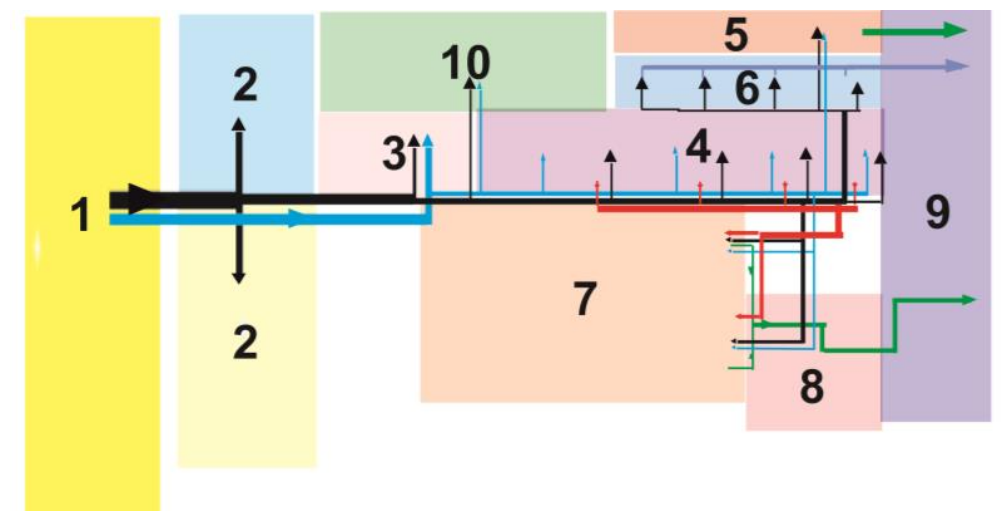

Fig. 1 Material flow and layout with marked sectors and production process: Sector 1 Inbound warehouse, Sector 2 - Preparation zone 1; Sector 3 - Preparation zone 2; Sector 4 - Zone for mode forming; Sector 5 - Production Line 1; Sector 6 - Zone for mode forming for production line 1; Sector 7 - Production Line 2; Sector 8 Electrical and Visual Control; Sector 9 - Training Zone

The material is delivered to the inbound warehouse. The wires are distributed in the Preparation zone 1 (Sector 2), for further processing. Then, the products from sector 2 as well as additional material for sector 1 are delivered to the Preparation zone 2 (Sector 3 ) and to the Zone for mode forming (Sector 4). As the production organization produces the final products for two types of vehicles, part of the semi-product is distributed to the Production Line 1 (Sector 5) and within this part is also individual Zone for mode forming for production line 1 only (Sector 6), which supplies that production line in particular.

The second production line - Production Line 2 (Sector 7) consists of two conveyor lines where the previously produced modes are installed. Products are then subjected to the Electric and Visual Control (Sector 8) and packaging and delivery to the Outbound warehouse (Sector 9).

\subsection{Energy profile of the industrial process}

In order to define the energy profile of a production organization, the proposed model for energy management is given [29] in Fig. 2, consisting of the following stages. The first step is to define the system boundary and to list all included processes/machines. The energy and material flows can be qualitatively sketched by walking through the site. The second step is to collect different types of data to quantify the flows, such as energy bills, machine specifications, material usage reports, data regarding production waste, production records, etc. Due to the lack of an energy metering system, the most challenging task is to break down energy consumption at the unit process level. However, a rough estimation of load factor can be made based on expert opinions, machine documentation, and published energy profiles of similar processes. In order to validate the estimation, the 
assumed load factors need to be reused for calculating different periods and compared with the energy bill. The comparison can be further used to adjust the assumptions for load factors. Finally, for the analyzed period the input and the output flow can be quantified. For the dynamic process, it is helpful to construct a more detailed process model that can be further validated with metering results. The generic information obtained from stage 1 can be used to form the baseline scenario. Stage 7 begins with screening improvement measures to select potential ones. It is necessary to review the detailed technical specifications and to compare them with the limitations of the current process. A technical feasibility report can be generated, which includes all advantages or disadvantages of each option. Another step is revisiting models with different scenarios, in order to compare the total energy consumption and other process parameters directly. The potentials for energy savings can be also predicted relatively accurately. After obtaining the cost information of each option, the financial feasibility study can be reported (Fig. 2).

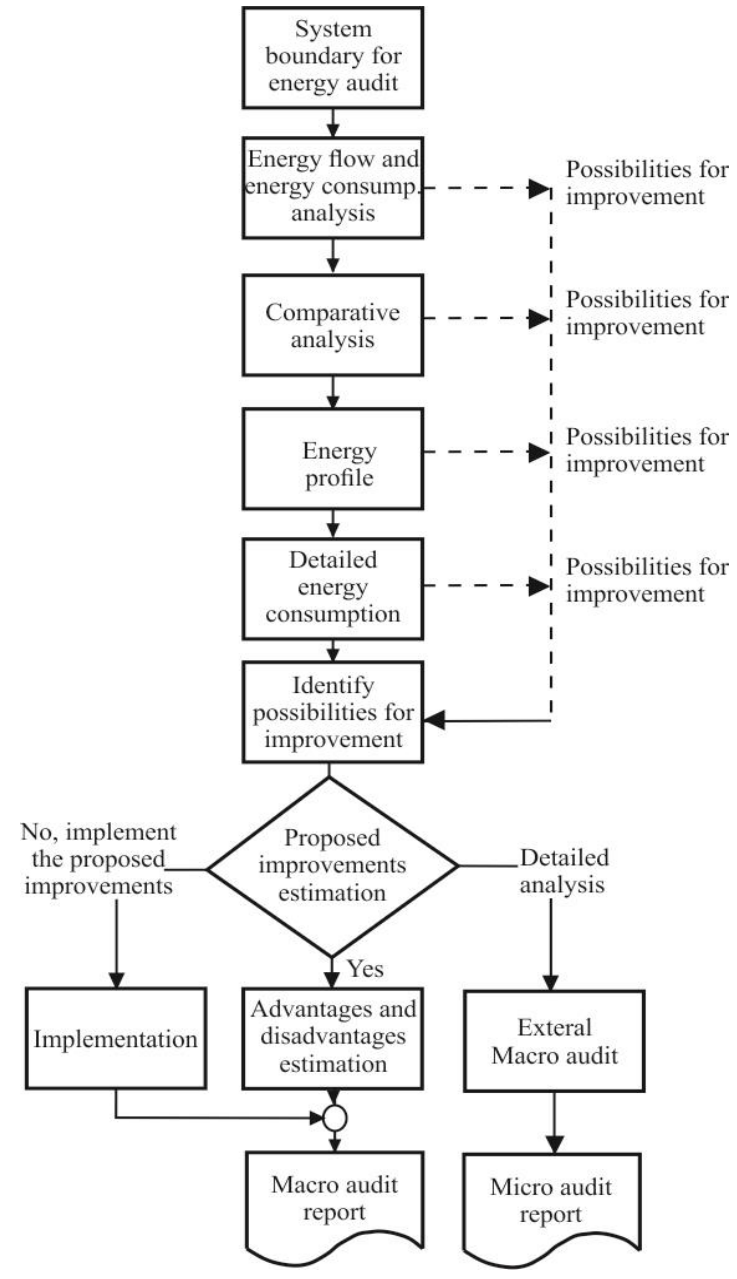

Fig. 2 The proposed energy management model on the process level [29] 
Defining the energy profile of the industrial process represents a systematic approach as well as the basis for future energy consumption planning. Introducing an energy profile enables the production organization and its management to analyze the current state of energy consumption, to plan energy resources and to analyze future activities to improve energy performance. However, it also provides crucial information on energy consumption parameters, the importance of rational energy use and its key role in sustainable business.

In order to determine the energy profile, it is important to identify critical consumers and provide a detailed insight into how much energy is spent on individual parts of the system that do not participate in the direct production process, but as a support. Such systems may involve the system of central heating, cooling and ventilation, lighting, hot water sanitary heating, etc. By using the machine design project as well as the on-site consumer identification, a list of the main consumers with installed power was made. These data were used to present the consumers and their energy demand (Fig. 3).

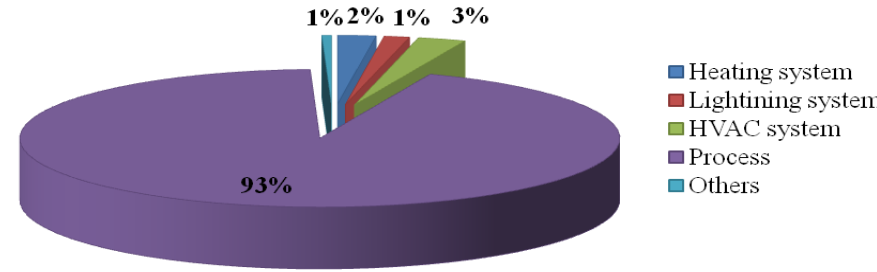

Fig. 3 Electricity demand overview in the production plant: Heating of administrative offices located in the production hall (2\% of the total electricity demand), Lighting (1\%), HVAC System (3\%), Production process (93\%) and other consumers (about 1\%).

Bearing in mind a five-day workweek in three shifts, i.e. 480 working hours and only the heating system in the administrative offices is turned on 8 hours a day, the profile of electricity consumption will not differ significantly from the situation shown in Fig.2. In order to identify the largest consumers, the critical machines and units are identified in the whole production hall. The graphical representation of the consumers, together with the compressed air system is shown in Fig.4.

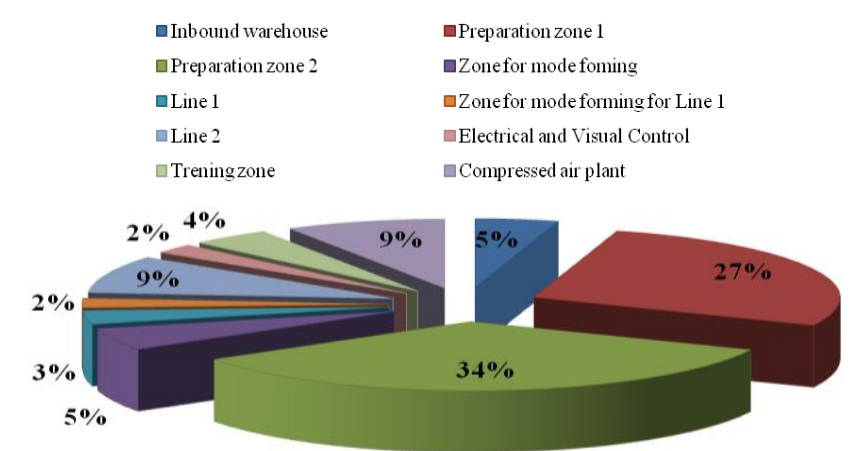

Fig. 4 Consumers overview in the production plant and their energy demand: Inbound warehouse (4\% electricity demand), Preparation zone 1 (27\%), Preparation zone 2 $(34 \%)$, Zone for mode forming $(5 \%)$, Production Line $1(3 \%)$, Zone for mode forming for Line 1 (2\%), Production Line 2 (9\%), Electrical and Visual Control (2\%), Training Zone (4\%), Compressed Air system (8\%) 
As shown in Fig.3, the largest consumers are almost all process units in production. In order to monitor the required electricity load, an annual overview for 2018 of electricity consumption by critical production sectors is given (Fig.5), where the biggest electricity consumption was recorded in March and October. The provided data regarding recorded energy consumption was used to present the energy performance indicators as part of the energy management system. The energy consumption model was formed in order to estimate future consumption in this production plant.

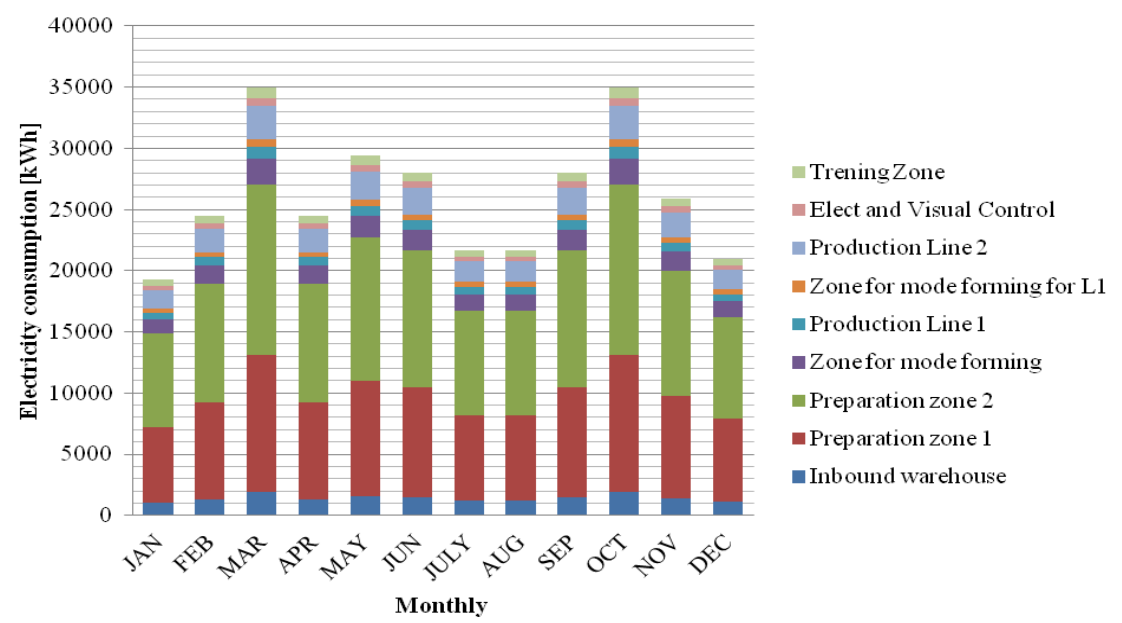

Fig. 5 Annual electricity consumption by production sectors for 2018 production year

\section{ENERGY PERFORMANCE INDICATOR}

The energy performance represents the amount of energy consumed (or estimated to be necessary) in order to meet the different needs. In industrial processes, it is defined as the realized consumption of energy and energy sources at the organization level in a certain period - a month or business year. Based on the data on electricity consumption, an overview of the energy performance of the considered processed can be given [38]. For analysis is necessary to define the concept of energy performance indicators. Energy performance indicators are defined as specific energy consumption at the organization level in a certain period - month and business year. Energy performance indicators are presented as a ratio:

$$
I P(t)=\frac{E(t)}{A(t)}
$$

where are:

$I P(t)$ - Energy performance indicator;

$E(t)$ - Amount of energy consumed;

$A(t)$ - Indicator of monitored activity for which energy is used (quantity of products/services, area of heated space and similar);

$t \quad$ - Period for which the energy performance indicator is calculated. 
It should be noted that due to the complexity of production in the preparation department (preparation zone 1 and 2), about 15,000-18,000 pieces of necessary elements are produced for two main final products, that will be used for analysis. The data refers to the daily number of final products produced in three shifts. As the production organization is in charge of two different projects - Project 1 and Project 2, the number of final product pieces will be expressed as P1 and P2. Electricity consumption data on a weekly basis are not precisely given, but adopted by using monthly consumption and the number of working hours in each week. Energy performance indicators are given for both final products delivered to the customer.

Fig.6 provides an overview of weekly energy performance indicators for products P1 and P2 during 2018. In this way, the lowest value of an indicator can be identified, when electricity is used minimally to reach operational capacity. The critical moments can also be observed when consumption is higher than usual, with the aim to analyze the causes. This can provide insight into various accident conditions, working failures, break downs in the process and also enable in a preventive way, to avoid such conditions in the future.

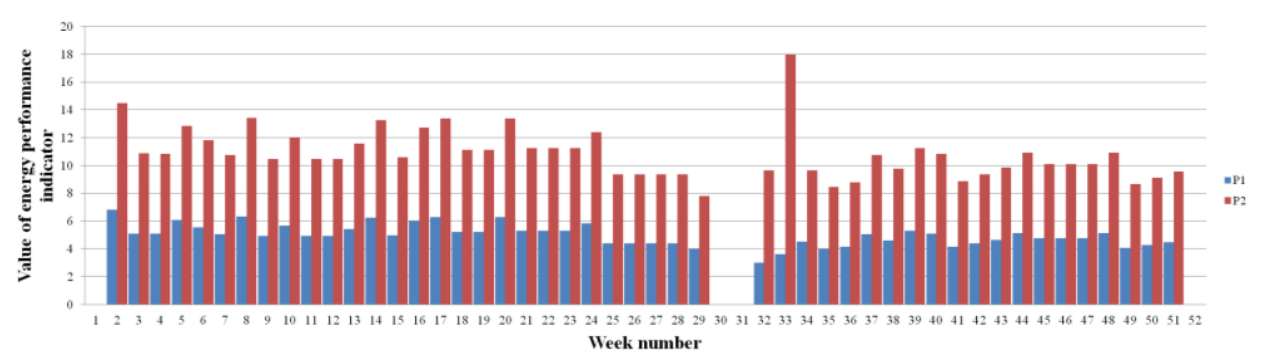

Fig. 6 Energy performance indicators for final product P1 and P2

\section{ENERGY CONSUMPTION MODEL}

The functional dependence between the effects of the production process (number of final products) in the industrial plant and the electricity consumption is mainly presented as a linear dependence [39-42]. In this way, it is possible to determine the functional dependence of the available data using the least-squares method. Fig. 7 shows the regression dependence for the

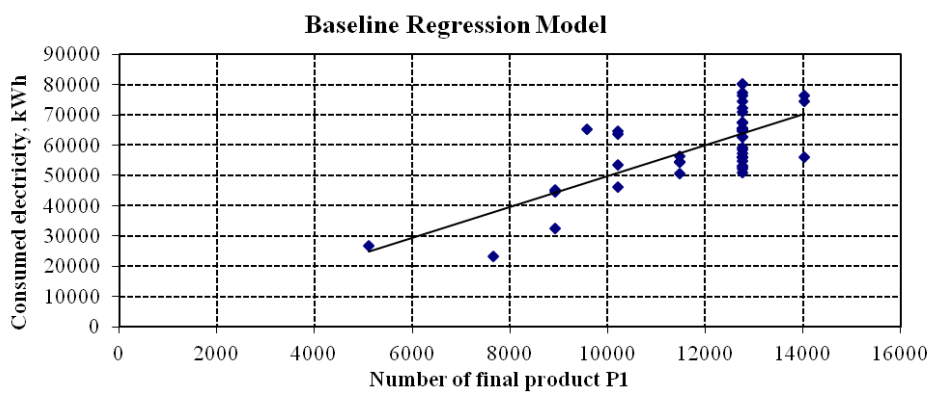

Fig. 7 Regression analysis of electricity consumption dependence and the number of final product P1 for 2018 
final product P1 that is observed. The regression analysis is performed by using the data on monthly production and energy consumption that is graphically presented in the Fig. 8 .

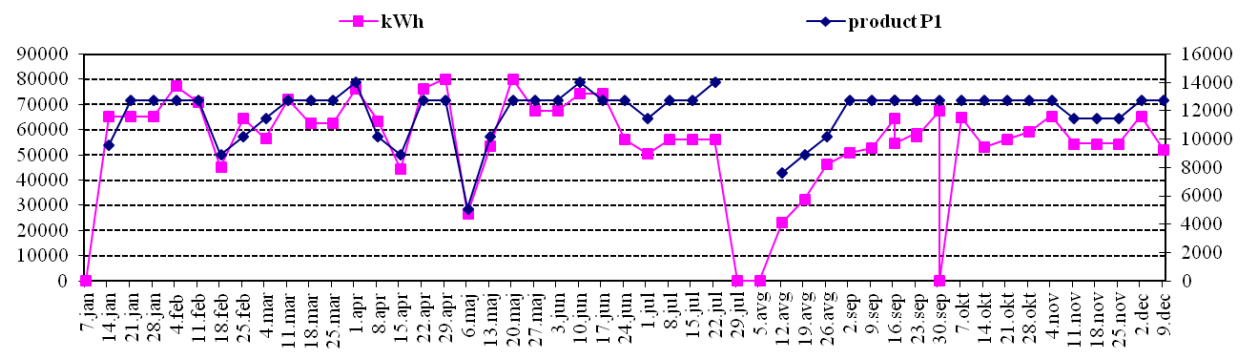

Fig. 8 Dependence of consumed electricity $[\mathrm{kWh}]$ and the number of final product P1

By using the available data, the functional dependence is determined as:

Electricity consumption $[\mathrm{kWh}]=5.011 \times$ final product $P 1-189.3205$

For further analysis of the electricity consumption model, the CUSUM technique or method of the cumulative sum of differences is introduced [43-47]. Its advantage is in identifying changes in forecasting, such as critical events and errors that occur. In this case, the sum of the differences refers to the differences between the actual consumption and the consumption expected by the forecast. If the consumption continues to follow the pattern previously defined, the differences between actual consumption and the established pattern become smaller and can reach negative values. Also, in some cases, the difference can be very close to zero. The curve that is formed represents a broken linear dependence, where every change in the slope of the curve indicates a change in the pattern, while all approximately linear parts indicate that the pattern is stable. The values obtained by this method are presented in Fig. 9.

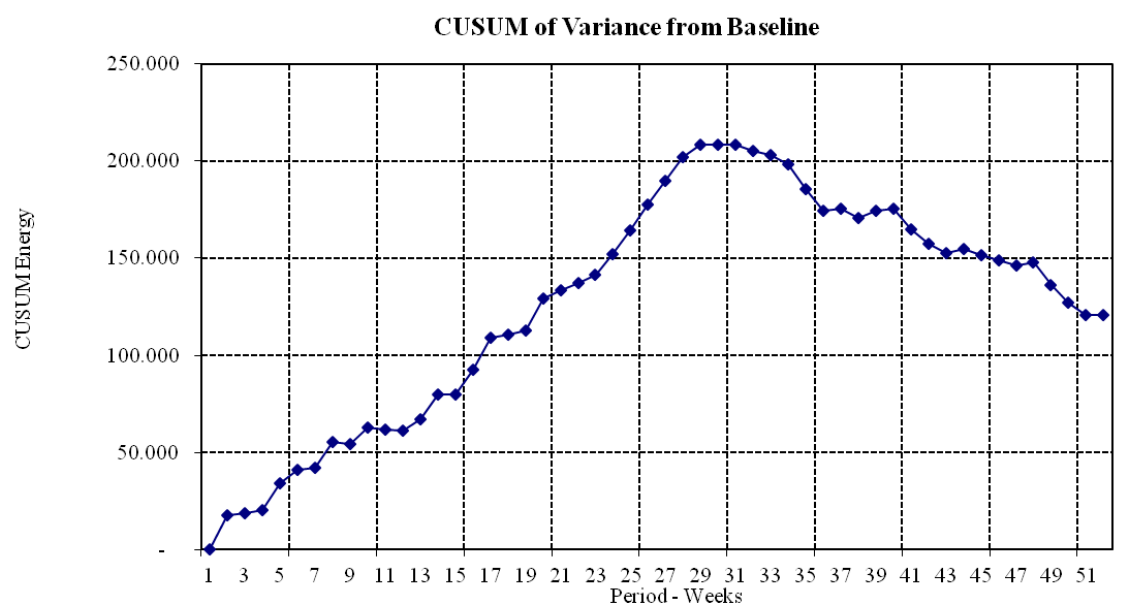

Fig. 9 Results of the method of the cumulative sum of differences for electricity consumption forecasting 
The critical points of this curve (Fig. 9) indicate changes in the slope, in the analyzed case even the direction of the slope of the curve, whose change is observed in the $30^{\text {th }}$ and $31^{\text {st }}$ week when the shutdown occurs and when there is no production and therefore no energy consumption. Based on the curve of the cumulative sum of differences, critical points can be adopted, whose development trend is considered suitable for the analyzed case and that is certainly the reduction of energy consumption and should be part of the curve that is approximately linear or corresponds to a linear dependence. The period between the $39^{\text {th }}$ and $46^{\text {th }}$ week was adopted, as a trend corresponding to the reduction of electricity consumption, which will be further taken into analysis.

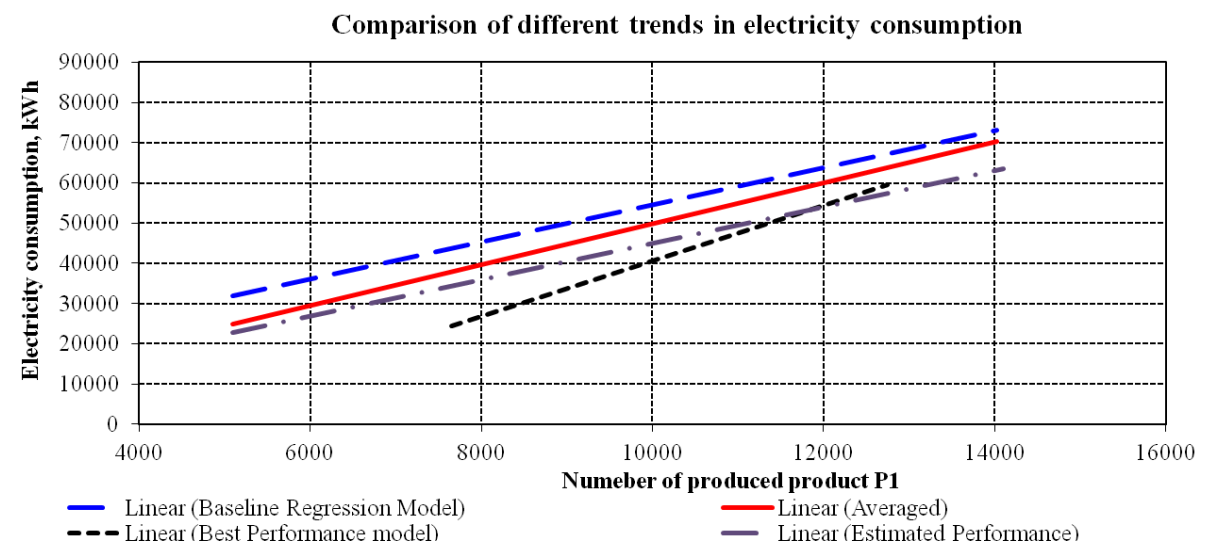

Fig. 10 Comparison of different trends in electricity consumption

Based on the obtained data in the previous steps, it is possible to compare the current consumption and values adopted as predictive, using the method of cumulative sums of differences and the best trend line thus adopted, as well as the average value of consumption during the production of P1 (for 22 months). The described analysis is presented in the common graph in Fig.10. It can be noted that the considered period in 2018 is above the average electricity consumption for the same number of final products $\mathrm{P} 1$ for 22 months. The projected consumption realistically reflects the growing trend of electricity consumption in proportion to the number of produced units. The linear dependence of the curve, which is marked as the best prediction, is the result of the chosen trend of the cumulative sum of differences, with the possibility of reducing electricity costs by $8 \%$ and indicating the lowest possible consumption that can be achieved for the same number of produced products P1. By further iterative procedure, it is possible to achieve better results of the prediction curve, applying also measures for electricity savings.

\section{CONCLUSION}

This paper presents a case study of the consumption energy model for material and energy flows in the production organization. The design of material and energy flows represents the basis of sustainable production processes in order to have minimal resource wastes and losses, but also to provide a positive impact on the environment. The aim was 
to examine energy flows in the manufacturing sector, to form an energy consumption model in order to foresee the possible scenarios in production. Higher energy consumption is related to the process itself, but also to the dynamic operations, that should be planned, controlled and monitored. The results of the presented case study indicate which processes consumed the largest amount of electricity in the previous period. Based on the available data, the energy profile of the organization was obtained; the energy performance indicators were presented, as well as the estimated consumption models. Also, the comparison of estimated consumption was made on the grounds of available data on production capacities and energy demands.

The complexity of the production processes has been analyzed so far by using the material flow; therefore, the energy flow and consumption are usually negligible. The proposed model includes production parameters that are changed on a daily basis, especially in a dynamic production environment such as the number of final products produced, number of working hours in each sector presented, number of effective hours as well as downtimes. The model that would be developed in future research should be in the form to follow the patterns that are established in production processes, but also able to foresee the consumption peaks and to provide sustainable and reliable operation without any unnecessary energy losses. Future research should be focused on developing a unique, general model of energy flows in production organizations and the possibility of harmonizing it with the current general material flow model.

Acknowledgment: This research was financially supported by the Ministry of Education, Science and Technological Development of the Republic of Serbia.

\section{REFERENCES}

1. Thiede, S., Posselt, G., Herrmann, C., (2013), SME appropriate concept for continuously improving the energy and resource efficiency in manufacturing companies, CIRP Journal of Manufacturing Science and Technology, Vol. 6, No. 3, pp. 204-211.

2. Duflou, J.R., Sutherland, J.W., Dornfeld, D., Herrmann, C., Jeswiet, J., Kara, S., Hauschild, M., Kellens, K., (2012), Towards energy and resource-efficient manufacturing: A processes and systems approach, CIRP Annals-Manufacturing Technology, Vol. 61, No. 2, pp. 587-609.

3. Suh, S., (2005), Theory of materials and energy flow analysis in ecology and economics, Ecological modelling, Vol. 189, No. 3, pp. 251-269.

4. Doty, S., Turner, W., (2009), Energy Management Handbook. The Fairmont Press.

5. Beer, J., (2000), Potential for industrial energy-efficiency improvement in the long term, Eco-efficiency in industry and Science, Springer, Vol. 5.

6. Ghadimi, P., Li, W., Kara, S., Herrmann, C., (2014), Integrated Material and Energy Flow Analysis towards Energy Efficient Manufacturing, 21st CIRP Conference on Life Cycle Engineering, Procedia CIRP 15, pp. $117-122$.

7. Fleiter, T., Eichhammer, W., Schleich, J., (2011), Energy efficiency in electric motor systems: Technical potentials and policy approaches for developing countries, United Nations Industrial Development Organization.

8. Yin, R.Y., (2011), Metallurgical Process Engineering, Springer Heidelberg, ISBN 978-3-642-13955-0, New York, USA.

9. Lu, Z.W., Cai, J.J., (2010), The Foundations of Systems Energy Conservation, Northeastern University Press, ISBN 978-781102-846-1, Shenyang, China.

10. Yin, R.Y., (2000), Analysis and Integration of Steel Manufacturing Process, Acta Metallurgica Sinica, Vol. 36, No. 10, pp. 1077-1084, ISSN 0412-1961.

11. Yin, R.Y., (2007), Some Science Problems about Steel Manufacturing Process, Acta Metallurgica Sinica, Vol. 43, No. 11, pp. 1121-1128, ISSN 0412-1961. 
12. Yin, R.Y., (2008), The Essence, Functions, and Future Development Mode of Steel Manufacturing Process, Scientia Sinica Technologica, Vol. 38, No. 9, pp. 1365-1377, ISSN 1674-7259.

13. Lu, Z.W., Cai, J.J., Yu, Q.B., Xie, A.G., (2000), The Influences of Materials Flows in Steel Manufacturing Process on Its Energy Intensity, Acta Metallurgica Sinica, Vol. 36, No. 4, pp. 370-378, ISSN 0412-1961.

14. Chen, G., Cai, J.J., Yu, Q.B., Lu, Z.W., (2002), The Analysis of the Influences of Materials Flows in Iron and Steel Corporation on Its Energy Consumption, Journal of Northeastern University (Natural Science), Vol. 23, No. 5, pp. 459-462, ISSN 1005-3026.

15. Cai, J.J., Wang, J.J., Lu, Z.W., Yin, R.Y., (2006), Material Flow and Energy Flow in Iron \& Steel Industry and Correlation between Them, Journal of Northeastern University (Natural Science), Vol. 27, No. 9, pp. 979-982, ISSN 1005-3026.

16. Cai, J.J., Wang, J.J., Zhang Q., Li, G.S., (2008), Material Flows and Energy Flows in Iron \& Steel Factory and Their Influence on CO2 Emissions, Research of Environmental Sciences, Vol. 21, No. 1, pp. 196-200, ISSN 1001-6929.

17. Korol, J., Kruczek, M., Pichlak, M., (2016), Material and energy flow analysis (MEFA) - the first step in the eco-innovation approach to the assessment of steel production, Metalurgija, Vol. 55, No. 4, pp. 818-820.

18. Fischer-Kowalski, M., (1998), Society’s Metabolism - The Intellectual History of Material Flow Analysis, Part I, 1860 - 1970, Journal of Industrial Ecology, Vol. 2, No. 1, pp. 61-78.

19. Fischer-Kowalski, M., Hüttler, W., (1999), Society's Metabolism - The Intellectual History of Material Flow Analysis, Part II, 1970 - 1998, Journal of Industrial Ecology, Vol. 2, No.4, pp. 107-136.

20. Saidur, R., Atabani, A.E., Mekhilef, S., (2011), A review on electrical and thermal energy for industries, Renew. Sust. Energy Rev., Vol. 15, No. 4, pp. 2073-2086.

21. Mizuta, Y., (2003), A case study on energy-saving and new energy services in Japan, Manag. Environ. Qual. Int. J., Vol. 14, No. 2, pp. 214-220.

22. Pardo Martínez, C.I., (2010), Energy use and energy efficiency development in the German and Colombian textile industries, Energy. Sustain. Dev., Vol. 14, No. 2, pp. 94-103.

23. Neelis, M., Patel, M., Blok, K., Haije, W., Bach, P., (2007), Approximation of theoretical energy-saving potentials for the petrochemical industry using energy balances for 68 key processes, Energy, Vol. 32, No. 7, pp. 1104-1123.

24. Madlool, N.A., Saidur, R., Rahim, N.A., Kamalisarvestani, M., (2013), An overview of energy savings measures for cement industries, Renew. Sust. Energy Rev., Vol. 19, pp. 18-29.

25. Siitonen, S., Tuomaala, M., Ahtila, P., (2010), Variables affecting energy efficiency and $\mathrm{CO}_{2}$ emissions in the steel industry, Energy Policy, Vol. 38, No. 5, pp. 2477-2485.

26. Backlund, S., Thollander, P., Palm, J., Ottosson, M., (2012), Extending the energy efficiency gap, Energy Policy, Vol. 51, pp. 392-396.

27. The World Bank, (2014), Energy use (kg of oil equivalent per 1000\$ GDP). http://databank.worldbank. org/data/

28. Republic Statistical Office of the Republic of Serbia, Energy Balances of the Republic of Serbia - final data, (2014), http://www.stat.gov.rs/publikacije/publication/?p=9434

29. Rajić, M., (2020), The Model of the Energy Flow Management in Industrial Systems, PhD Thesis, University of Novi Sad, Faculty of Technical Sciences, Novi Sad, Serbia.

30. Rajić, M., Maksimović, R., Milosavljević, P., Pavlović D., (2020), Energy Management System Application for Sustainable Development in Wood Industry Enterprises, Sustainability, Vol.12, Iss.1, No. 76, pp. 1-16.

31. Böttcher, C., Müller, M., (2016), Insights on the impact of energy management systems on carbon and corporate performance. An empirical analysis with data from German automotive suppliers, Journal of Cleaner Production, Vol. 137, pp. 1449-1457.

32. Bornschlegl, M., Kreitlein, S., Bregulla, M., Franke, J., A., (2015), Method for Forecasting the Running Costs of Manufacturing Technologies in Automotive Production during the Early Planning Phase, Procedia CIRP, Vol. 26, pp. 412-417.

33. Franz, E., Erler, F., Langer, T., Schlegel, A., Stoldt, J., Richter, M., Putz, M., (2017), Requirements and Tasks for Active Energy Management Systems in Automotive Industry, Procedia Manufacturing, Vol. 8, pp. $175-182$.

34. Ghazanfari, B., (2015), Modeling Energy Consumption in Automotive Manufacturing, PhD Thesis, University of Windsor.

35. Giacone, E., Mancò, S., (2012), Energy efficiency measurement in industrial processes, Energy, Vol. 38, issue 1, pp. 331-345

36. Fysikopoulos, A., Anagnostakis, D., Salonitis, K., Chryssolouris, G., (2012), An Empirical Study of the Energy Consumption in Automotive Assembly, Procedia CIRP, Vol. 3, pp. 477-482. 
37. Feng, L., Mears, L., (2016), Energy Consumption Modeling and Analyses In Automotive Manufacturing Plant, Journal of Manufacturing Science and Engineering, Vol. 10, No. 138, pp. 1-11.

38. Tasić, N., Đurić, Ž., Malešević, D., Maksimović, R., Radaković, N., (2018), Automation of Process Performance Management in a Company, Tehnicki vjesnik - Technical Gazette, Vol. 25, No 2, pp. 565572, ISSN 1330-3651, UDK: 10.17559/TV-20151010074417.

39. Energy Savings Toolbox - An Energy Audit Manual and Tool, Canadian Industry Program for Energy Conservation (CIPEC), https://www.nrcan.gc.ca/.

40. Grinbergs, K., (2013), Energy audit method for industrial plants, 4th International Conference Civil Engineering`13 Proceedings Part I Industrial Energy Efficiency, 2013, pp. 350-355.

41. National Renewable Energy Laboratory (NREL), (2005), Procedure to Measure Indoor Lighting Energy Performance.

42. SRPS ISO 50002:2017, Energy audits - Requirements with guidance for use.

43. Đorđević, M., Mančić, M., \& Mitrović, D. (2014),. Energetska i eksergetska analiza termoelektrane na fosilna goriva. Facta universitatis - series: Working and Living Environmental Protection, 11(3), 163-175.

44. Lakovic, M., Banjac, M., Jović, M., Mitrović, D., (2015)., Coal-Fired Power Plants Energy Efficiency and Climate Change-Current State and Future Trends, Facta Universitatis Series: Working and Living Environmental Protection, 12(2), pp. 217-227.

45. Alwan, L. C., (1986), CUSUM Quality Control-Multivariate Approach, Communications in Statistics Theory and Methods, Vol. 15, pp. 3531-3543.

46. Woodall, W. H., Ncube, M. M., (2012), Multivariate CUSUM Quality - Control Procedure, Technometrics, Vol. 27, Issue 3, pp. 285-292.

47. Rajić, M., Milovanović, M., Antić, D., Maksimović, R., Milosavljević, P., Pavlović, D., (2020), Analyzing Energy Poverty Using Intelligent Approach, Energy \& Environment, 0958305X2090708. doi: 10.1177/0958305X20907087.

\section{MODEL ZA UPRAVLJANJE ENERGIJOM U CILJU ZAŠTITE ŽIVOTNE SREDINE U INDUSTRIJI}

Održivo poslovanje i pozicioniranje kompanija na tržištu zahteva od kompanija da maksimiziraju dodatu vrednost uz minimalno iskorišćenje resursa. Sve veći izazov za kompanije predstavlja racionalna upotreba energije i energetskih izvora, a sve sa ciljem očuvanja životne sredine. Industrijski sistemi, pre svega proizvodni sistemi, predstavljaju najveće potrošače energije. Potreba za ovakvom temom je pritisak evropske regulative na primenu mera za uštedu energije, kao i za zaštitu životne sredine. Standardi za sistem menadžmenta energijom, na kojima se ovo istraživanje zasniva, razmatraju energetsku performansu i indikatore energetske performance koju postiže organizacija. Jedan od najpoznatijih predstavnika ove vrste standarda je ISO 50001. Ovaj rad ima za cilj da analizira potrebu za energijom u jednomj proizvodnoj organizaciji, da ima potpuni uvid u tok materijala $i$ energije u procesu, kako bi se formirao model za upravljanje energijom. Model je razvijen koristeći procesne parameter koji se menjaju na dnevnom nivou.

Ključne reči: upravljanje energijom, tok energije, zaštita životne sredine, industrijski sistemi, analiza tokova materijala i energije. 